University of Nebraska - Lincoln

DigitalCommons@University of Nebraska - Lincoln

Civil and Environmental Engineering Faculty

Publications

Civil and Environmental Engineering

2018

\title{
Land Suitability Analysis for Emergency Medical Services Posts along State Highways: A Case Study of California
}

\author{
Ernest Tufuor \\ University of Nebraska - Lincoln, ernest.tufuor@huskers.unl.edu \\ Laurence Rilett \\ University of Nebraska - Lincoln, Irilett2@unl.edu \\ Yunwoo Nam \\ University of Nebraska-Lincoln, ynam2@unl.edu \\ Antonio Hurtado Beltran \\ University of Nebraska-Lincoln
}

Follow this and additional works at: https://digitalcommons.unl.edu/civilengfacpub

Part of the Civil Engineering Commons, and the Transportation Engineering Commons

Tufuor, Ernest; Rilett, Laurence; Nam, Yunwoo; and Hurtado Beltran, Antonio, "Land Suitability Analysis for Emergency Medical Services Posts along State Highways: A Case Study of California" (2018). Civil and Environmental Engineering Faculty Publications. 171.

https://digitalcommons.unl.edu/civilengfacpub/171

This Article is brought to you for free and open access by the Civil and Environmental Engineering at DigitalCommons@University of Nebraska - Lincoln. It has been accepted for inclusion in Civil and Environmental Engineering Faculty Publications by an authorized administrator of DigitalCommons@University of Nebraska Lincoln. 


\title{
Land Suitability Analysis for Emergency Medical Services Posts along State Highways: A Case Study of California
}

\author{
Ernest O. A. Tufuor ${ }^{1}$, Laurence R. Rilett ${ }^{1}, \underline{\text { Yunwoo Nam }}{ }^{1}$, Antonio Hurtado \\ Beltran ${ }^{1}$ \\ University of Nebraska-Lincoln, Lincoln, NE \\ Corresponding Author: Ernest O. A. Tufuor: ntc-etufuor@unl.edu
}

Published in Transportation Research Record 2672(32), Volume: 2672 issue: 32, page(s): 94-106

Article first published online: October 18, 2018;

Issue published: December 1, 2018

https://doi.org/10.1177/0361198118798293

Transportation Research Record 2018, Vol. 2672(32) 94-106

(c) National Academy of Sciences: Transportation Research Board 2018

DOI: 10.1177/0361198118798293

Publisher's version is online at:

https://journals.sagepub.com/doi/full/10.1177/0361198118798293 


\section{LAND SUITABILITY ANALYSIS FOR EMS POSTS ALONG STATE HIGHWAYS - A CASE STUDY OF CALIFORNIA}

Ernest O. A. Tufuor, Corresponding Author

Graduate Research Assistant

University of Nebraska-Lincoln

330Q Prem S. Paul Research Center at Whittier School

Lincoln, NE 68583-0851

Tel: 402-472-0141; Email: ntc-etufuor@unl.edu

\section{Yunwoo Nam, Ph.D.}

University of Nebraska-Lincoln

College of Architecture

Arch 314

Lincoln, NE 68503

Tel: 402-472-9279; Email: ynam2@unl.edu

\section{Laurence R. Rilett, Ph.D.}

Director, Nebraska Transportation Center

Keith W. Klaasmeyer Chair in Engineering and Technology

University of Nebraska-Lincoln

262D Prem S. Paul Research Center at Whittier School

Lincoln, NE 68583-0851

Tel: 402-472-1992; Email:1rilett2@unl.edu

Word count: 4,986 words text +9 tables/figures x 250 words (each) $=7,236$ words 
1 ABSTRACT

2 The response time of Emergency Medical Services (EMS) to road accidents can be the difference

3 between life and death. The California strategic highway safety plan highlight the need to

4 improve the response time and recognizes that: $37 \%$ and $8 \%$ of the fatal crashes are 30 or more

5 miles away from a trauma center in rural and urban areas respectively.

The paper seeks to: (1) demonstrate the viability of using spatial multi-criteria analysis in road safety management, and (2) provide a good scientific justification in selecting optimal counties for EMS posts. The goal is to propose areas that are close to probable fatality points in order to achieve a maximum response time of 10 minutes (i.e., 3 minutes below the national 10 average).

This paper adopted a multi-criteria analysis using the weighted linear combination 12 method on raster data of various impact factors. The land selection criteria were: (1) close to 13 probable road fatality locations, (2) far from existing trauma centers, (3) close to existing rest 14 stop areas, and (4) not on protected lands or bodies of water.

The method proved viable and the analysis resulted in 37,387 square miles of suitable land areas. About 7\% moderately suitable and 69\% were unsuitable. The highway corridors linking the counties between Los Angeles and San Francisco were the most suitable locations. Other identified high suitable areas were predominantly rural counties such as Amador and Calaveras. A benefit-cost analysis is recommended in future studies to determine the suitability of specific sites within the identified counties.

Keywords: California, fatality, response time, GIS, suitability analysis, EMS post 


\section{INTRODUCTION}

The level of injury severity of people involved in road accidents has been strongly correlated to the delay in the response time of first responders or first aiders. That is to say, early response is known to save lives and drastically reduce the injury severity level (1). In most instances, emergency services can be the difference between life and death. For example, chances of surviving a sudden cardiac arrest decrease an estimated $10 \%$ for every minute of delay in treatment (2). The response time provides a useful measure to locate or relocate an EMS post or ambulance service.

The reports from the Fatality Analysis Reporting System (FARS) of the National Highway Traffic Safety Administration (NHTSA) have shown that Medical Emergency Services (EMS) response times in fatal road accidents in the United States have improved little over the past few years. The improvements have been based in urban settings were ambulance or hospital accessibility is often in close proximity to accident locations. However, this trend does not seem to be the same for some rural areas in the State of California.

California is the most populous state in the United States with a population of about 39.1 million (3). There were 3,176 fatal crashes reported in 2015 which was the second highest in the United States (4). Traffic crashes cost California more than $\$ 22$ billion every year (5). The average response times for EMS after being notified of a fatal crash are 43 minutes and 5.92 minutes for rural and urban locations, respectively (6). It should be noted that the report did not have enough data to support the rural EMS response time. However, the California Strategic Highway Safety Plan (SHSP, 2015-2019) supports the rural need in this regard. It states that $37 \%$ of fatal collisions are 30 or more miles away from a trauma center in rural California and $8 \%$ for urban areas (7).

These high delays in EMS responses are unacceptable and need to be curtailed. There may be various ways of providing solutions to this problem. One of the quickest solutions is to provide EMS posts close to accident prone areas on the highway corridor in order to reduce the EMS response time. Therefore, this research questions how to propose a suitable area for the construction of EMS along road corridors in California that are prone to fatal crashes.

The objective of this study is to use GIS-based suitability analysis to optimize appropriate locations for the construction of accident EMS posts along highways in California. The goal is to achieve a maximum EMS response time of 10 minutes which is 3 minutes below the national average. It must be noted that California is the only state where statutory responsibility of the EMS system rests predominately with local EMS agencies (LEMSAs) (8).

There are two main contributions of this research: (a) demonstration of the viability of using GIS-Multi Criteria Analysis in road safety management, and (b) to provide a good scientific background and justification to assist LEMSAs to select the appropriate land for accident EMS posts. This will ultimately help to reduce the number of road transport fatalities and facilitate the achievement of California's EMS funded grant goals (9).

\section{Description of Study Area}

The state of California has 58 counties with Sacramento as the state capital. It covers 155,779 square miles, and it is the most populous and the $3{ }^{\text {rd }}$ biggest state in the United States (3). It is covered with state parks and forestry and the land is undulating. Noticeable cities with high levels of crash fatalities are Los Angeles, San Diego, and San Francisco. Rural crash fatalities make up about $46 \%$ of the total fatalities in the state (4) and are mostly concentrated in the southern and central regions, as shown in Figure 1a. 
One of the overall goals of the California State Trauma System incorporated in the State Trauma Plan is to provide timely access to trauma care (8). However, there is wide disparity between locations of rural and urban accident sites and trauma centers or facilities (7), as illustrated in figure $1 \mathrm{~b}$.

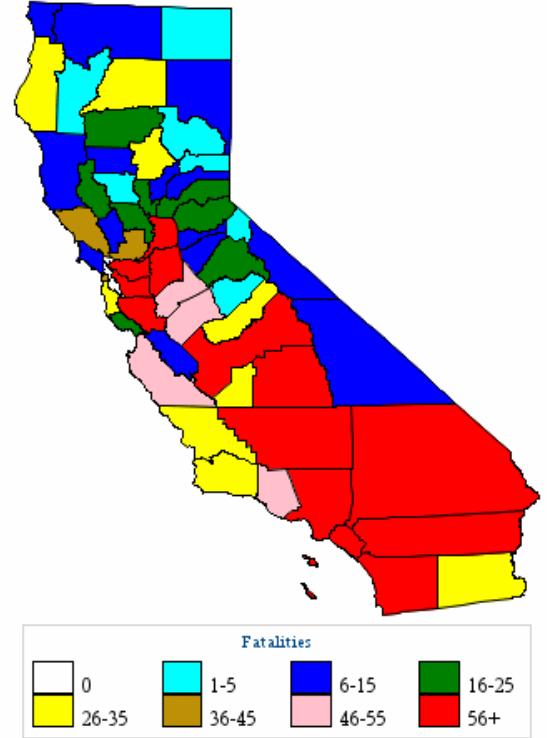

(a) source: FAR (4)

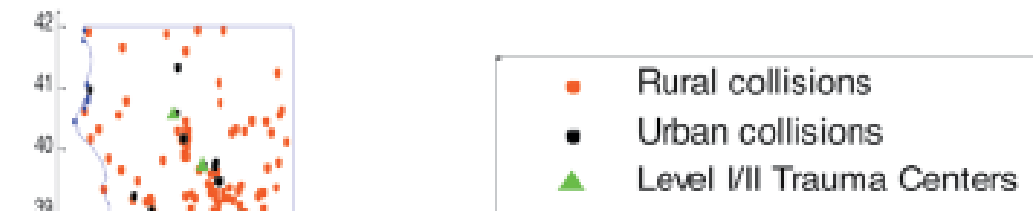

(b) source: $\operatorname{SHSP}(7)$

FIGURE 1 Graphic representation of (a) the 2015 fatalities, and (b) fatal crashes and trauma center locations.

\section{LITERATURE REVIEW}

\section{Emergency Medical Services in California}

Most road safety plans have the 4Es of safety: education, enforcement, engineering, and EMS. All of these safety dimensions play a part in reducing crash severity levels, and consequently, fatalities. EMS is involved in two ways: (1) quick response time, and (2) high-quality medical care at the scene and on route to a hospital or trauma center. Other contributing factors include accurately locating the site of the incident, and providing instructions to 911 callers before arrival. In all of these, the most important aspect is arriving on the scene quickly.

The SHSP (2015 -2019) reports that "one of the reasons fatalities have decreased over the last 20 years is due to the advancements in emergency services." The focus was getting treatment to injured persons at a hospital within the first hour, which is called the "golden hour". However, it is important to remember that the quality of treatment provided by the first responders' plays a very essential role within this golden hour. Not surprisingly, there is a wide disparity between rural and urban areas in terms of the closeness of fatal accident locations to trauma centers, as can be seen in figure $1 \mathrm{~b}$.

The strategy for EMS as outlined in the SHSP is as follows: (1) increase involvement by EMS leaders in the California SHSP, (2) develop strategies to improve the time to definitive care, (3) improve data from the time of the crash, and (4) improve access to information to enable interoperability of communications, and improve safety at the crash scene. This paper is focused on strategy (2) by providing scientifically optimal locations to LEMSA to ascertain suitable land across California where EMS posts can be established. 
Multi-criteria Analysis

Investigating suitable land use locations within a given area requires a versatile tool that will enable a visual and statistical modeling of the interaction among the determining factors. GIS Land Suitability Analysis, also known as Multi-Criteria Analysis (MCA), was chosen to provide this function. GIS-based land suitability analysis is a tool used to enable planners and engineers to analyze the interactions among location and, environmental and developmental action factors (10). Many GIS programs allow users to express simple spatial operations using map algebra, and with maps as variables to develop land-use suitability models.

The ArcGIS system was chosen for spatial modeling of the problem although other software could be used. It provides a flowchart approach that can be easily understood to build the land-use suitability models. In this flowchart approach individual processes from input and derived data are linked together. Collins et al (10) identified three major approaches to GIS landuse suitability analysis as: (1) computer-assisted overlay mapping, (2) multi-criteria evaluation methods, and (3) soft computing or geo-computation methods. The authors gave a detailed overview with spatial analysis in the United States.

The following illustrates the process and criteria used by some researchers in the MCA method that will be useful in understanding what factors to consider in this paper. Basnet et al. (11) selected a suitable land for animal waste applications using a raster GIS. The attributing factors were classified and weighted using the analytical hierarchy process (AHP). The suitability level was found to be a function of the weight distribution of the factors. Rodman et al (12) examined the land suitability for the placement of wind turbines in the ninecounty region in the Greater San Francisco Bay Area, California. The authors considered physical factors (e.g., land availability), environmental factors (e.g., vegetation, endangered plant species and wetlands), and human factors (e.g., urban and recreation locations).

Charabi and Gastli (13) demonstrated this approach incorporating the FLOWA module (in a fuzzy methodology) to assess the land suitability for large photovoltaic farms. The module allows for the incorporation of the uncertainty of expert opinions on the weightings and criteria. The authors used nine (9) factors that are likely to affect the optimum location. Key factors included: land use, land slope, sand/dust risk, grid proximity, and sensitive areas.

Sanchez-Lozano et al (14) also adopted the MCA to evaluate solar farm locations in south-eastern Spain. The key selected criteria were: planning regulations, protected areas, road networks, railways, waterways, and mountains. The weightings on each criterion were influenced by how much of an effect each had on achieving the set objectives of the studies.

Frazier (15) undertook a land suitability analysis for an inland port to service the ports of Los Angeles and Long Beach in the Southern California region. The author used eight variables which included: slopes and intersections, nearest railway lines, school proximity and population, and reduction in the miles traveled by trucks. Interestingly, the weightings were considered to be the same since it was difficult to estimate the most influential variable.

\section{Literature Review Summary}

41 The review emphasizes the need for this research. No detailed study was found on the location of suitable land for EMS posts based on accident hotspots in California.

The MCA evaluation method that relies on the Boolean overlay operators and weighted summations or linear combinations was found to be mostly used. The review gave a general idea of the important factors to consider in a land-use MCA method. These effects can be basically grouped as physical, environmental or protected areas, and human factors. The weightings given to each factor depends on their contributing effect in achieving the research goal. These weights 
are mostly derived from decision makers by comparing a change from the least-preferred to the most-preferred attribute or effects. To achieve this, some researchers argue for the use of the AHP pairwise comparison method $(16,17)$, and others for the swing weights technique $(18,19)$. However, all of these have drawbacks because of the subjective nature of the allocations (20, 21).

The reason for the popularity in use of the weighted linear combination method is the ease of its understanding and implementation within the GIS environment. However, the nature of the selected grid size can give misleading outputs (19). Smaller grid-cells are preferred to distinguish minute differences between suitability levels.

\section{METHODOLOGY}

To achieve the study objective, three key steps were undertaken:

1. data collection

2. model development, and

3. ArcGIS analysis and results.

\section{Database Development}

A land suitability analysis involves gathering the necessary data to apply a criteria and weightings to select the optimal sites. The considered determining factors were: location of fatal crashes, existing health facilities for emergency cases, topography and land cover, highways \& rest stops, lakes, national parks $\&$ reserves, and county boundaries. The source and a brief description of the data are summarized as follows:

- Geographic location of fatal crashes was obtained from the University of California, Berkeley (22). This offered an interactive map-centric approach to viewing and querying collision data. A query for fatality locations was done over the years to identify frequent accident locations.

- State highway network and post-mile GIS database was used to geographically represent the highways and post-mile point feature classes in California. Each record in the line layer represents a highway segment where the county, route, post-mile prefix, and postmile suffix are the same, and each segment has a beginning and end post-mile. The postmile layer displays valid post-mile points at $0.1(1 / 10$ th $)$ mile intervals. Both layers were created based on Caltrans SHN data as of September 4, 2015 (23).

- Safety roadside rest areas provide opportunities for travelers to safely stop, stretch, take a nap, use the restroom, get water, check maps, place telephone calls, switch drivers, check vehicles and loads, and exercise pets (24). The geographical locations can be helpful and ultimately used as EMS post s.

- The geographic location of existing health facilities was obtained from the Office of Statewide Health Planning \& Development. This provides a detailed description of the health facility. It includes hospital type, nature of facility, urban or rural, type of operations etc. (25).

- The California Department of Fish and Wildlife shape files for lakes in California was used to geographically represent the raster map for lake areas to be avoided during model development. The data is part of the GIS clearinghouse that is reliable and frequently updated (26). In addition, a GIS shapefile for the protected areas database (27) was used to further determine raster areas that are not preferable for EMS post s. Distances of $1,000 \mathrm{ft}$. away from lakes and protected areas were considered as preferred locations. An average travel speed for most California state roads is known to be $70 \mathrm{mph}$ (28). Considering 
the EMS target of 10 minutes to arrive at a probable accident sites, the implication is that a maximum distance of $6,160 \mathrm{ft}$. will be preferable for an EMS post. Therefore, $6,160 \mathrm{ft}$. is used as the suitable buffer around determined fatal accident locations.

The multiple variables that represent the impact factors on the EMS post land suitability were geographically modelled using ArcGIS version 10.4. The data was mapped, converted to raster format, and resampled to a cell size that gave a compactible resolution for the overlay analysis. The collected data were projected and transformed to North American Datum 1983 State Plane California VI FIPS 0406 (US Feet) and the North American 1983 geographical coordinate system was used. The purpose of this was to avoid any displacement, offset or inappropriate overlay of data and to also operate according to the norms of the State.

\section{Model Development}

The procedure for the model development is illustrated in the flow chart (Figure 2). Firstly, 2010 census data map of every county in California is used as the base map for a spatial representation of each determining factor. A distance measure is created on each map and values reclassified with scores from 1 to 4 . The score is used to rank raster cells with regards to the level of relevance. The value of 1 is the least suitable and 4 is the most suitable. For example, a cluster of $6160 \mathrm{ft}$. distance increment is created around each located rest stop area on the highway. In this particular case, a score of 1 is program to represent distances far from the rest stop area and the preferred score of 4 is for areas within 10 minutes' drive from the rest stop.

Secondly, the weighted linear combination method, which is one of the key methods often applied in land-use suitability analysis (19), is adopted. The rasterized layer maps created from each determining factor are printed out and combined using predetermined influence percentages. These weightings were selected based on their individual influence in achieving the set study objective. It must be noted that this is usually determined by a panel of experts based on the type of studies. However, it is not far-fetched to select the influence levels as shown in Table 1. For example, locations close to identified fatality sections on the highway will be more preferred than sites close to a rest stop. Although highway rest stops have readily available land or offices for the establishment of the EMS post, they are not necessarily located close to fatal crash sites to help reduce response time.

Finally, the combined map is smoothed using the neighborhood statistics function which creates visually attractive maps for the simplicity of analysis. The Environmental Systems Research Institute explains that the function calculates focal statistics for each cell of an image based on a defined focal neighborhood. The developed model layout in ArcGIS is given as Figure 3.

TABLE 1 Decision Rules and Weightings

\begin{tabular}{|c|c|}
\hline DECISION RULES & INFLUENCE (\%) \\
\hline Close to fatality points $(\leq 6160 \mathrm{ft})$. & 30 \\
\hline Far from existing hospitals & 30 \\
\hline Away from protected land areas $(\geq 1000 \mathrm{ft})$. & 20 \\
\hline Close to rest stop areas & 15 \\
\hline Away from lakes $(\geq 1000 \mathrm{ft})$. & 5 \\
\hline
\end{tabular}


1

2

3

4

5

6

7

8

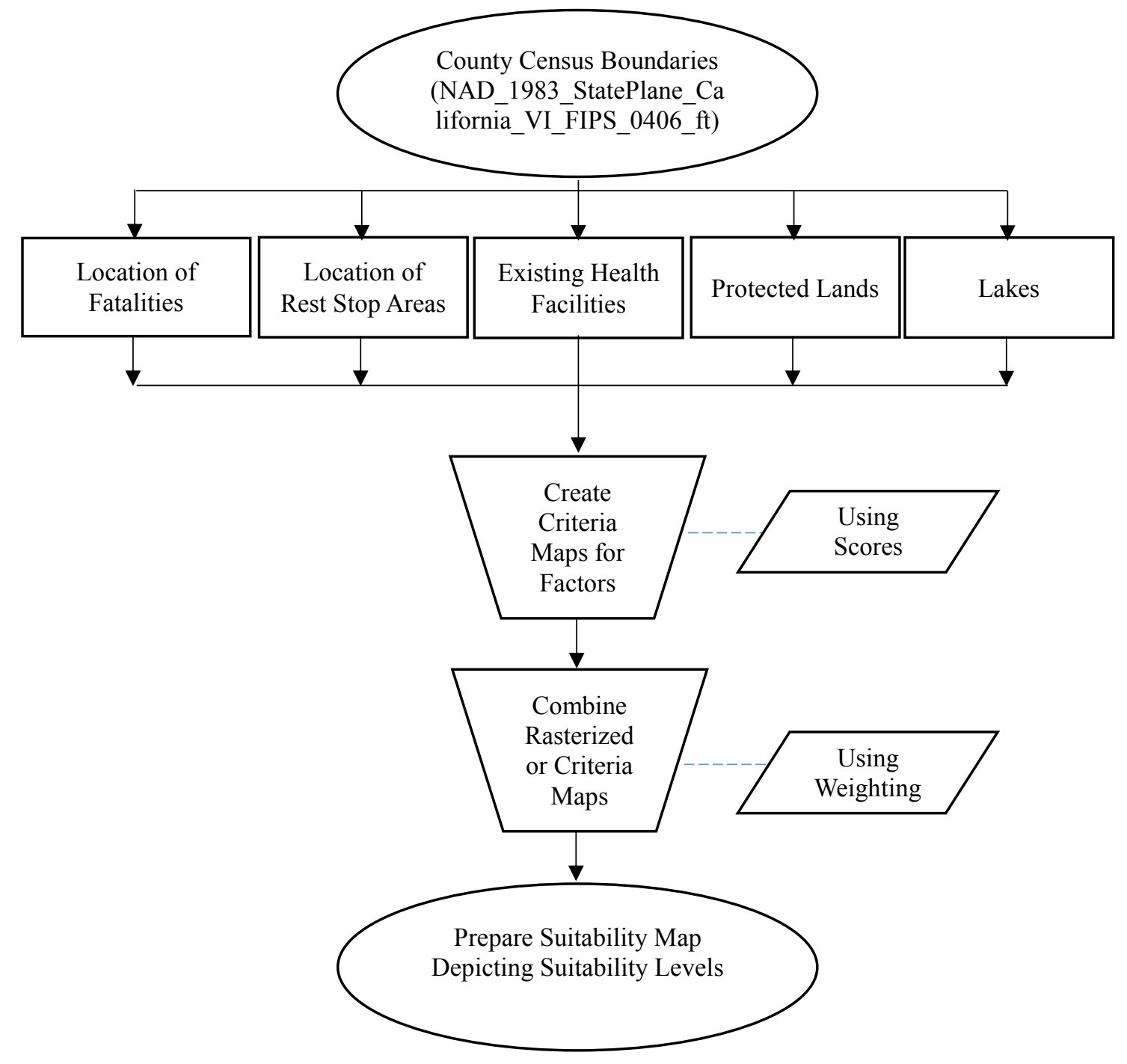

FIGURE 2 Flow chart for model development. 


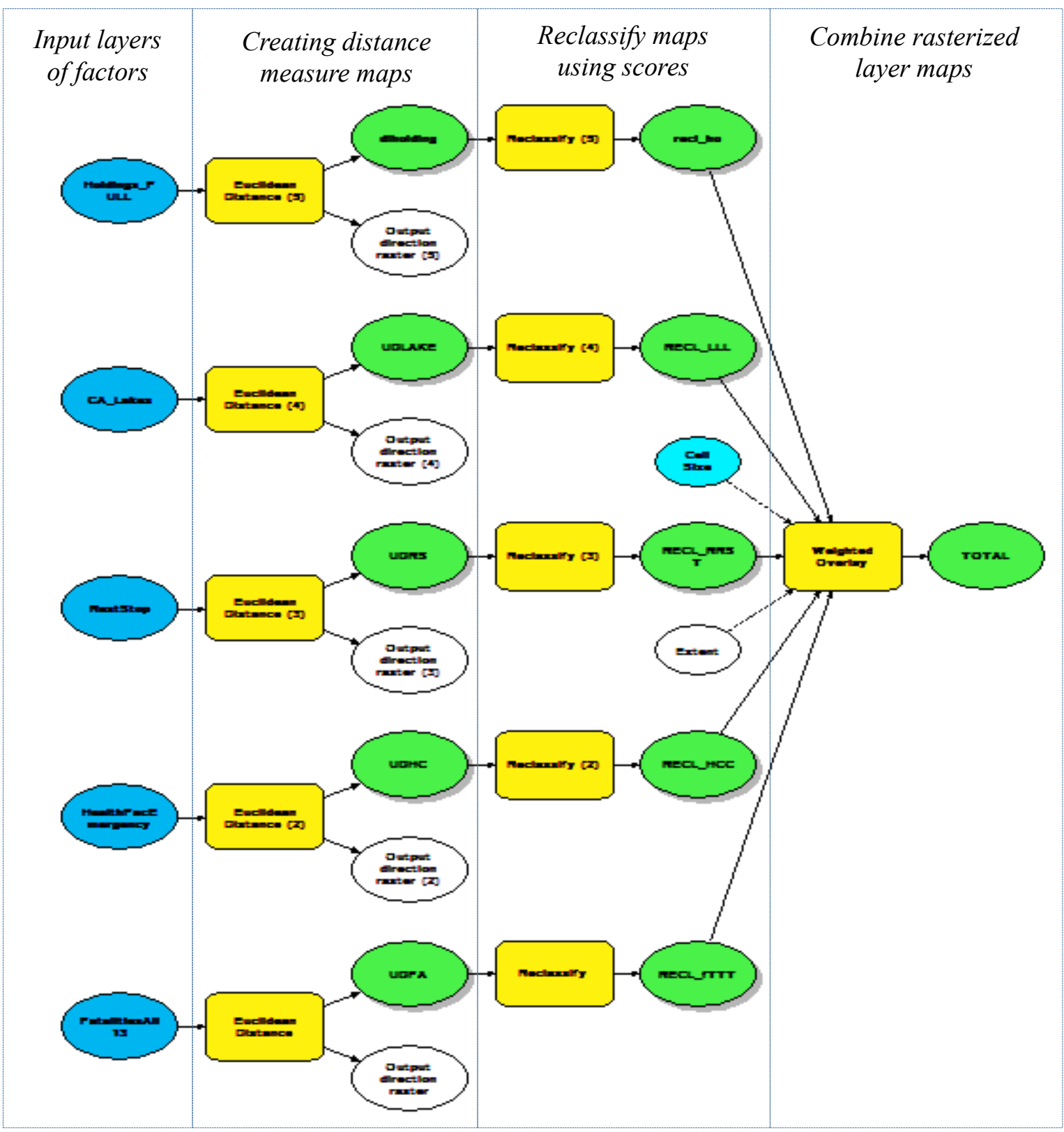

FIGURE 3 ArcGIS applied model layout

\section{RESULTS AND ANALYSIS}

It is important to show the relationship between the two most highly weighted impact factors in determining the suitable land i.e. location of fatal crashes and existing hospitals. Figure 4 illustrates a density map of fatal crashes and the location of these hospitals. It may be seen that the location of fatal crashes is mostly in the urban areas especially Los Angeles and San Francisco. This finding conforms to literature (7). Also the urban peripherals on state highways linking both cities have a sizable amount of fatal crashes. Similarly, the hospitals are well concentrated in the urban areas relative to the rural (7). 


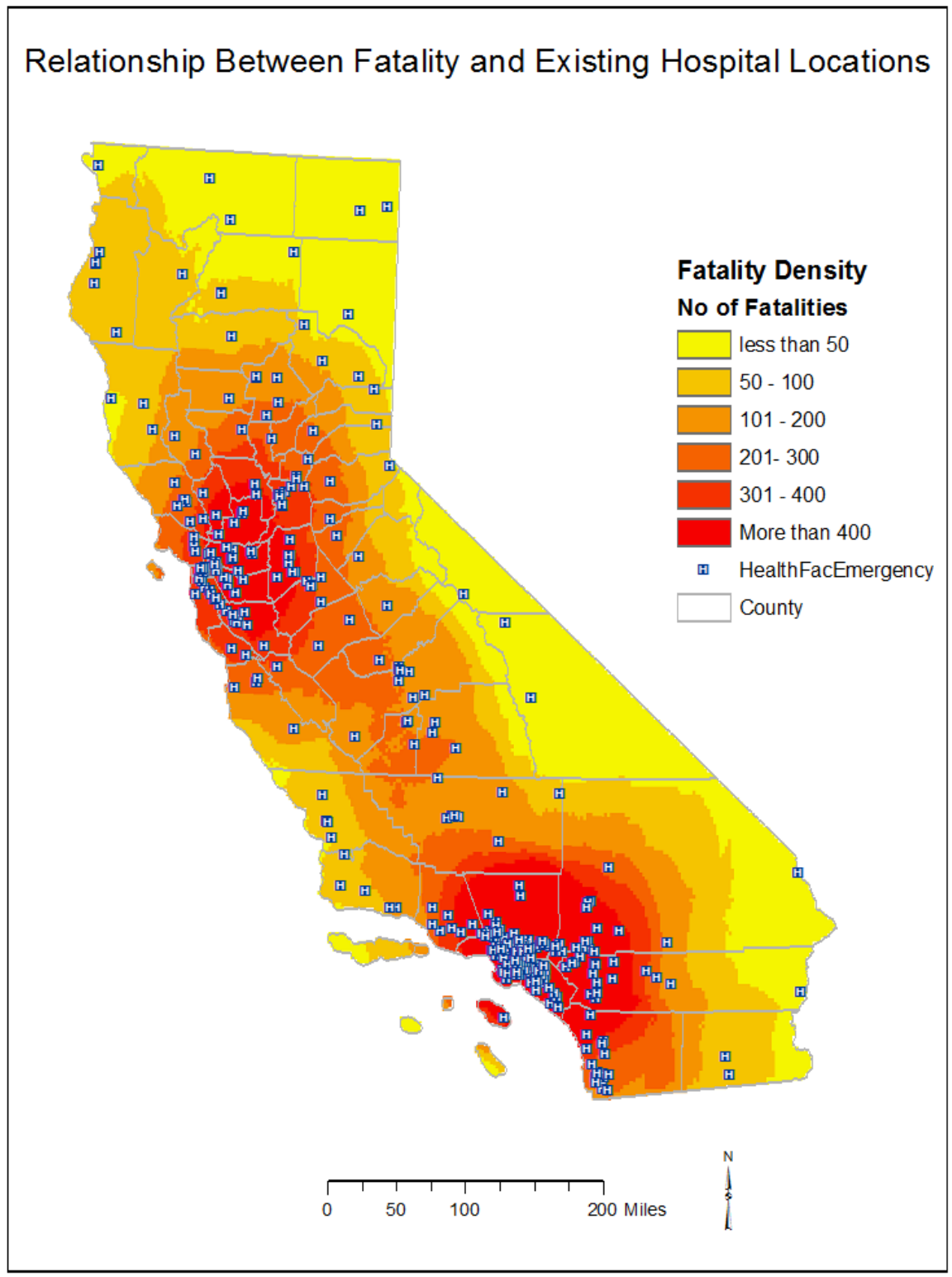

FIGURE 4 Spatial relationships between fatal accident locations the hospitals.

\section{Rasterized Maps}

Figure 5 shows the rasterized maps for the impact factors, and it depicts the suitable areas per each factor. It may be seen that the suitable areas are generally along the central and western regions. Various striking similarities exist in comparison with other maps in literature. For example, the land-holding suitability map clearly depicts the location of California's national parks as unsuitable, which is expected. It may be seen that using only one criterion may result in unreliable spatial estimates. Combining raster of several determining factors minimize the level of uncertainty and improve on the optimization process. 
1

2

3

4

5

6

7

8

9

10

11

12

13

14

15

16

17

18

19

20

21

22

23

24

25

26

27

28

29

30

31

32

33

34

35

36

37

38

39

40

41

42

43

44

45

46

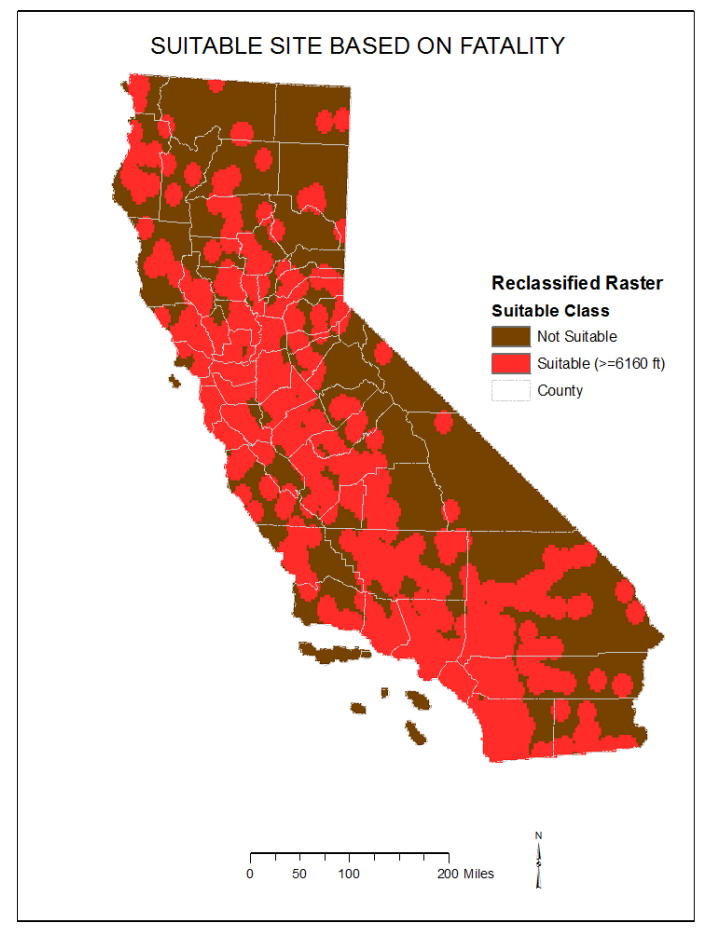

(a)

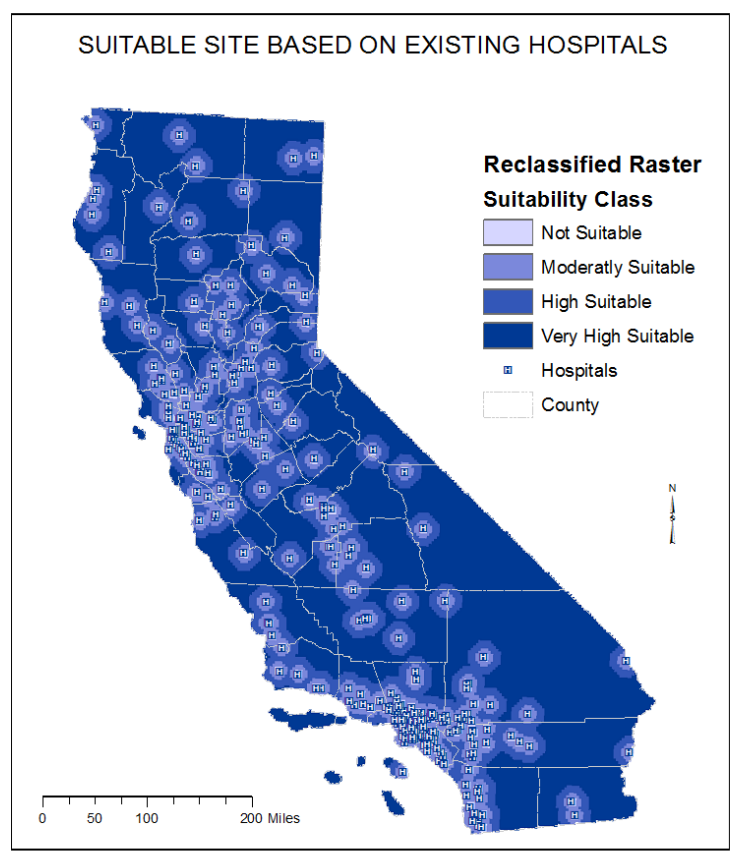

(c)

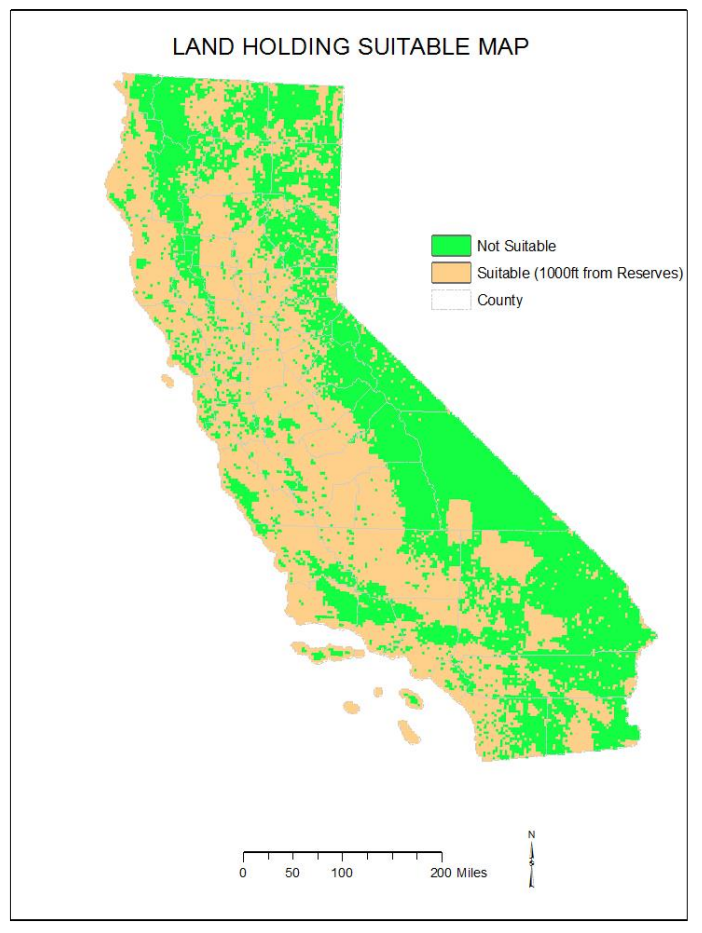

(b)

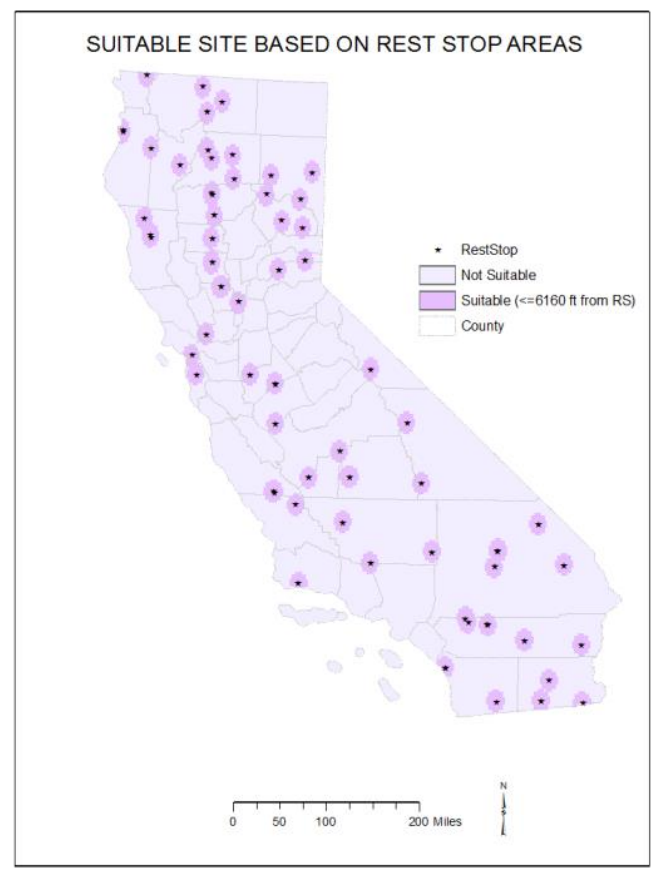

(d)

FIGURE 5 Rasterized maps showing suitable locations per criteria (a) fatalities, (b) protected land, (c) hospitals, and (d) rest stop areas. 


\section{Combined Rasterized Map}

2 The rasterized maps are combined and smoothened as shown in Figure 6a. It may be seen that 3 that the study area is divided into six levels of suitability categories: very low, low, moderate, 4 high, and very high suitable land. Comparing this suitability map with the individual criteria maps and the weightings assigned to each impact factor, it can be seen that it depicts the characteristics of the impact factors. The very high suitability areas are along the highways in the middle sections within counties linking the northern region to the south (i.e., from San Francisco to the outskirts of Los Angeles.)

Figure $6 \mathrm{~b}$ is a base topo map of California used to validate the database for especially the lake and the protected land (i.e., forestry and national parks in this case). Some similarities in terms of unstable areas can be seen between these maps. For example, the location of the Death Valley national park is clearly shown as 'very low suitable' on the combined raster map.

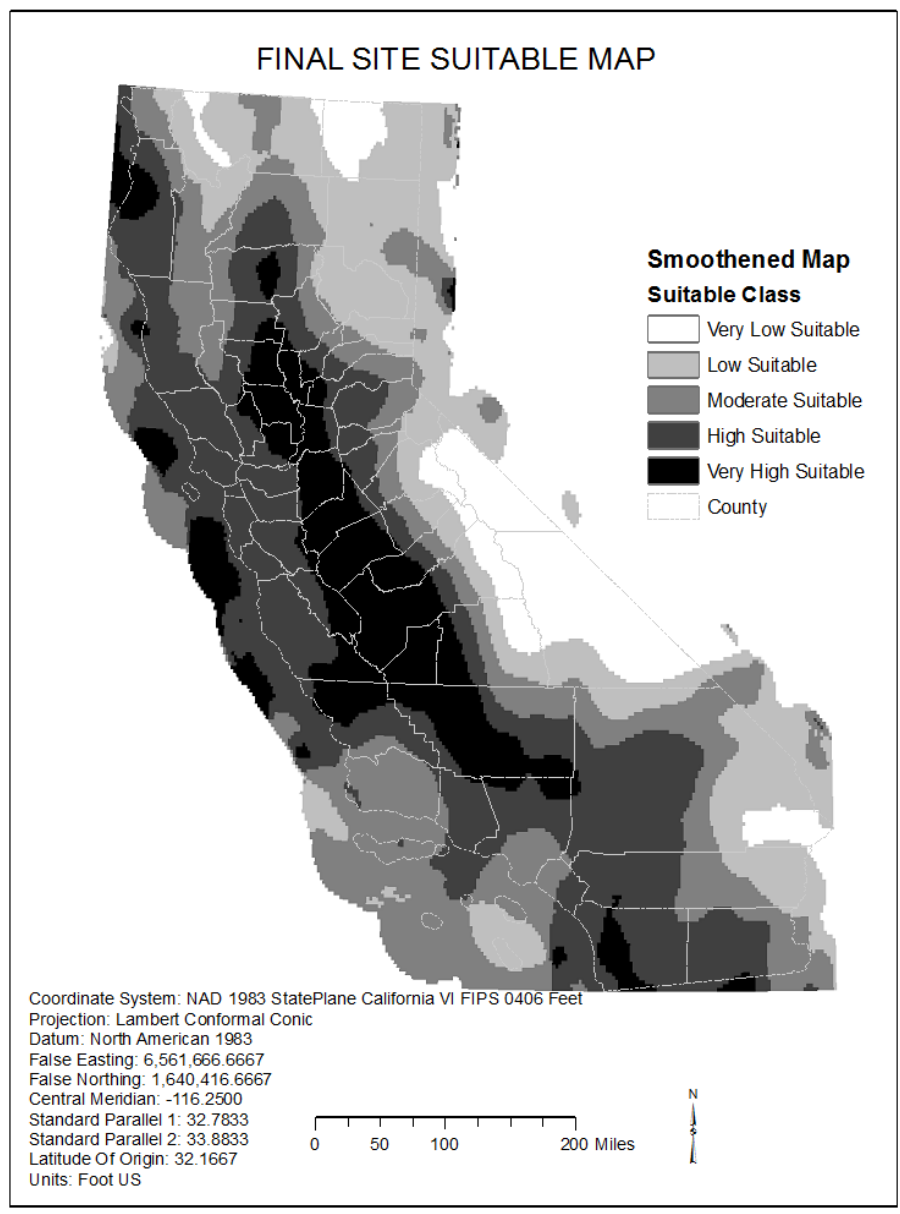

(a)

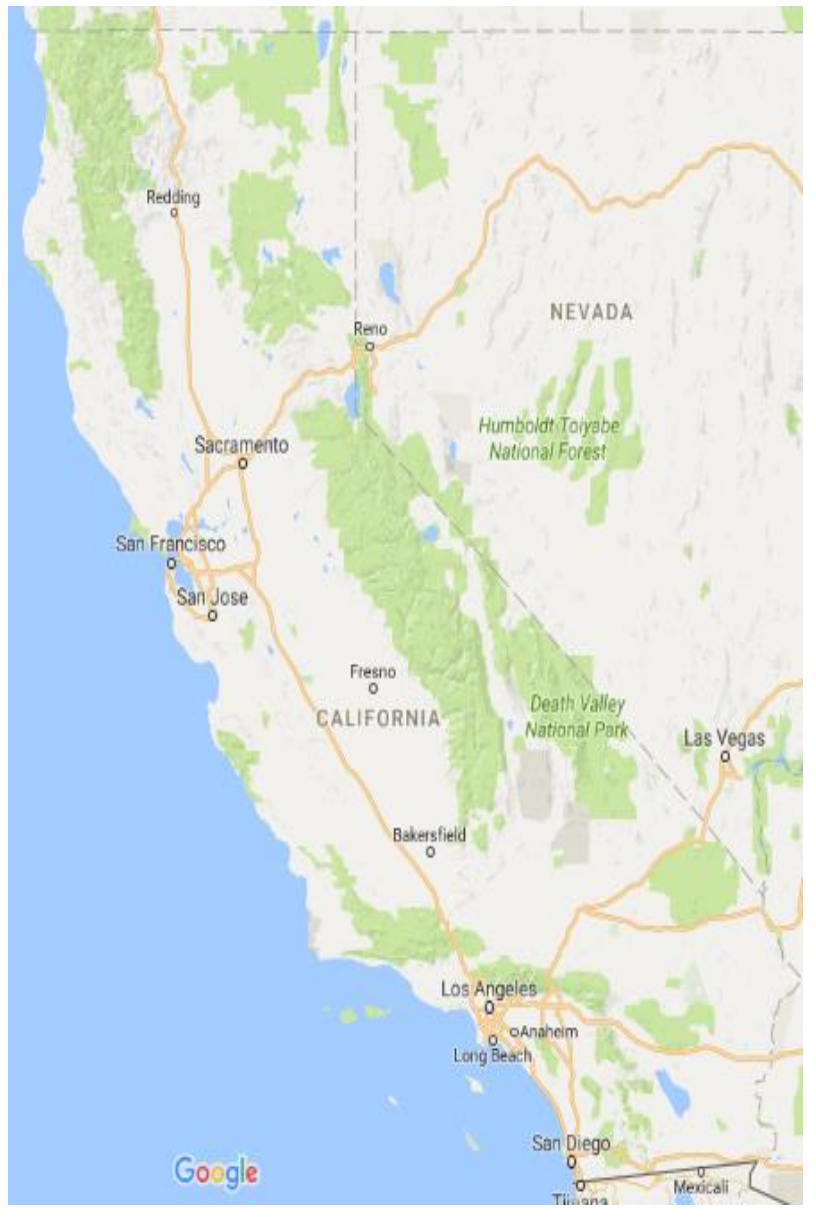

(b)

FIGURE 6 Map showing (a) the final combined rasterized EMS post suitability areas, and a (b) comparison base topo map from Google linking northern California through the central part to the south region. A total of $24 \%$ of the land size are within high to very high suitability levels (37,387 sq. mi), unsuitable to low suitability 
levels covers $69 \%$, and the rest are moderately suitable.

Figure 7 indicates the suitable land for the northern region. It may be seen that specific locations along Highway 45, Highway 5, and Highway 70 in Colusa County, Sutter County, Yolo County, and Sacramento County can be prioritized on top of the suitability listed areas. It should be noted that rest stop locations along these listed counties can be considered first since minimum capital outlay may be required to establish the EMS posts at the already built rest stop areas.

Predominantly rural counties (i.e. where more than $50 \%$ of the county population lives in a rural area) such as Plumas, Sierra, Amador, Calaveras (29) can also be prioritized. Amador and Calaveras are within the high suitable level.

\section{PRIORITIZED SUITABLE LOCATIONS - NORTH REGION}

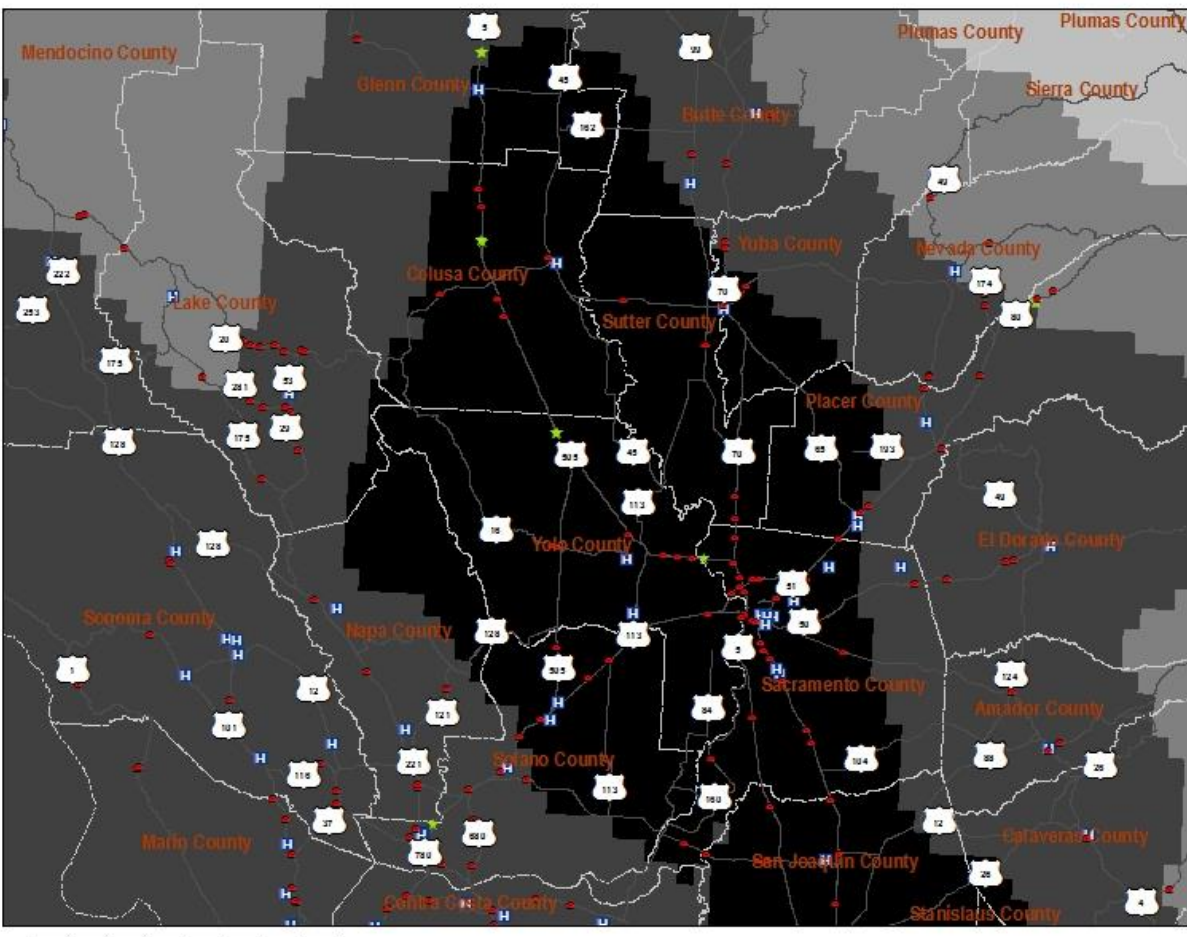

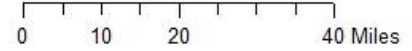

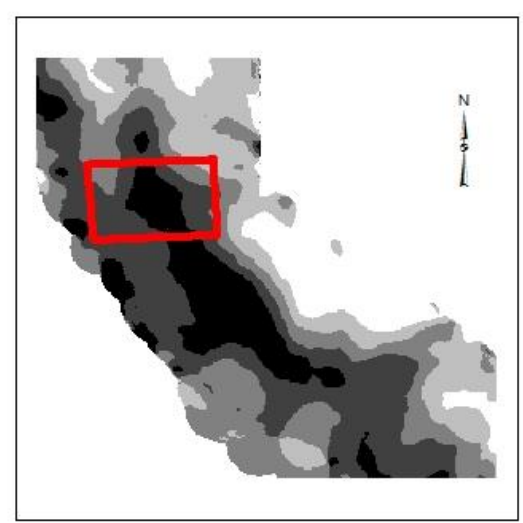

Legend

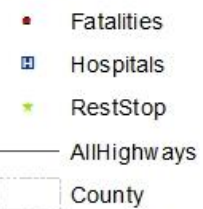

Smoothen Map Suitable Class

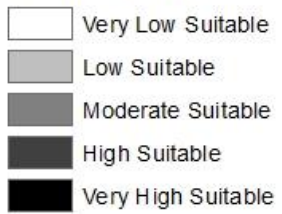


Figure 8a also shows the suitable land for the central region. These include; San Joaquin County, Stanislaus County, and Merced County. Specific locations along Highway 33, Highway 5, and Highway 152 can be prioritized.

Very high suitable land for the southern region is shown in figure 8b. Locations along Highways 5, 33, and 41 in Fresno County, Kings County, Kern County, and San Bernardino counties can also be prioritized.

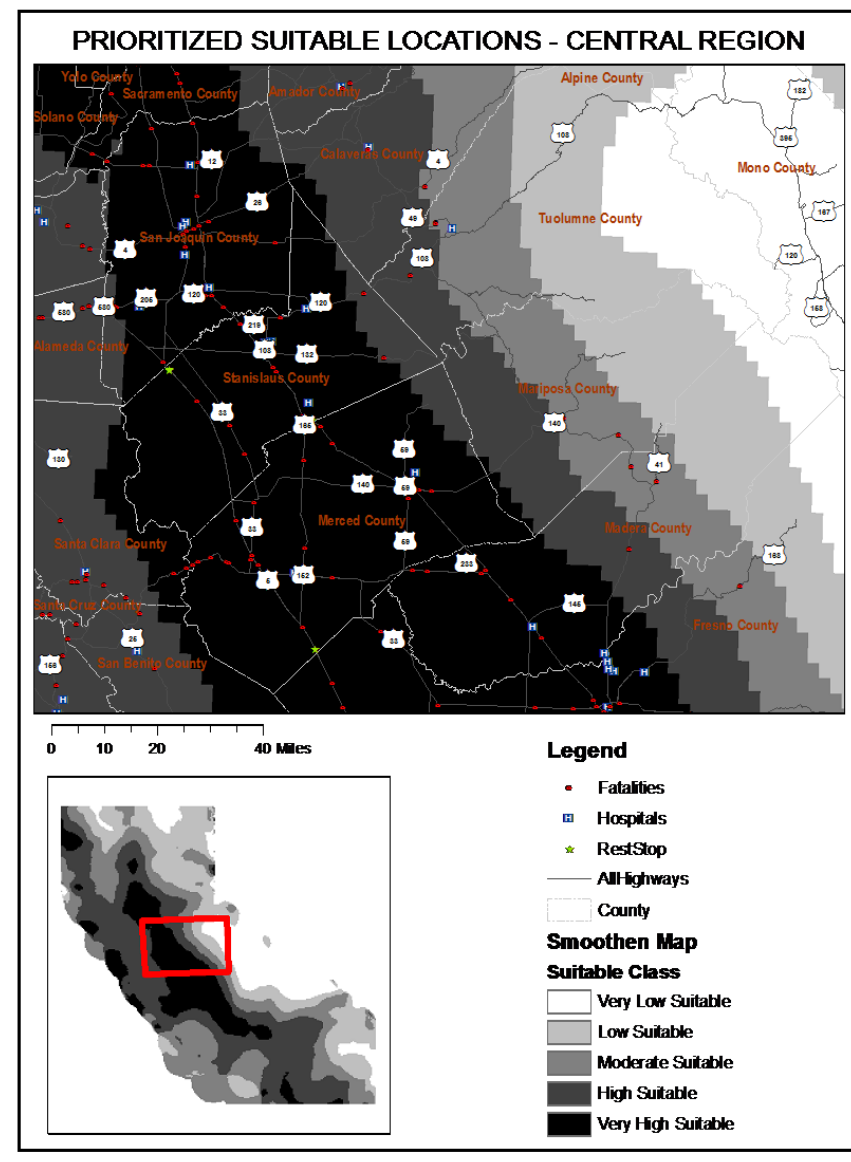

(a)

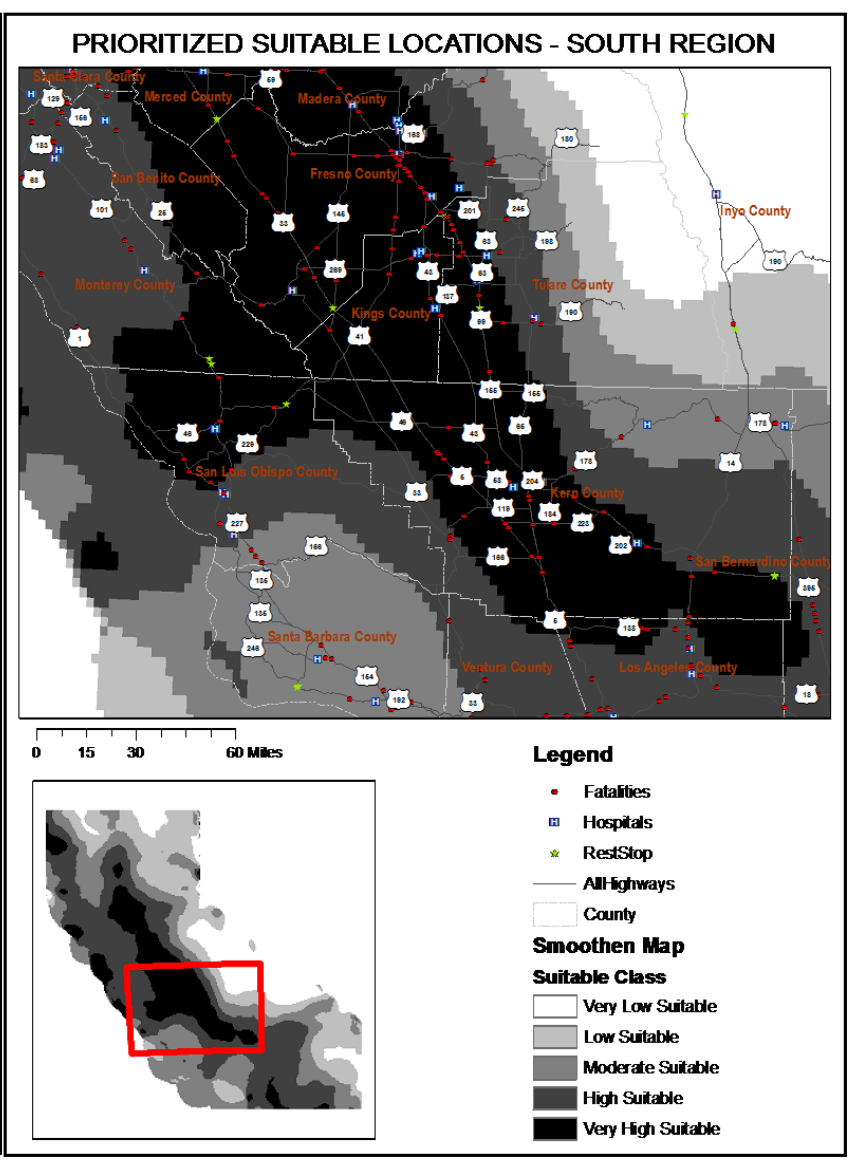

(b)

Figure 8 EMS land suitability maps along highways in central and southern California regions

\section{CONCLUDING REMARKS}

The objective of this study was to use GIS-based suitability analysis to optimize appropriate locations for the construction of accident EMS posts along highways in California. The goal is to relocate EMS close to fatal accident locations to achieve a maximum response time of 10 minutes (i.e. 3 minutes below the national average), which is about $1 / 6^{\text {th }}$ of the 'golden hour'.

Land-use suitability analysis using GIS has evolved in many fields and has once again been proven in this paper to be a valuable tool for the optimization of suitable EMS land in road safety management. The paper presented the results of the GIS MCA using the weighted linear 
combination method for the raster analysis. The results will be useful to provide a good scientific background and justification to assist LEMSAs to select optimal land for accident EMS posts.

The study found that the highway corridor linking the city of Los Angeles to San Francisco within the middle sections of California are the most suitable locations for building EMS posts. A total of $24 \%$ of the land size are within high to very high suitability levels and about $69 \%$ were unsuitable. Preferable locations were along corridors of Highways 5, 33, 41, 45, 70, and 152 within Colusa County, Sutter County, Yolo County, Sacramento County, San Joaquin County, Stanislaus County, Merced County, Fresno County, Kings County, Kern County, and San Bernardino County. Predominantly rural counties such as Amador and Calaveras were identified as high suitable locations.

The rest stop areas within the identified suitable counties can be prioritized for immediate establishment of EMS posts because of the low capital outlay that may be involved relative to other suitable locations. These rest stop EMS posts can also serve other medical needs of travelers. The paper recognizes the high cost involved in constructing a standard EMS post (i.e. about US\$760,000 per station (30) and therefore proposes a small size medical units as first responders in most of the locations. A benefit cost analysis is recommended in future studies to determine the suitability of specific sites within the identified counties.

The results provide insight information that can be embraced by decision-makers in relocating EMS. More precise outcomes can be achieved by considering more attributes and improving the weightings pertaining to rural California. Acquiring expert opinion can be used in future research to accurately predict the weightings of the impacting factors. It should be noted that applying the weighted linear combination method to smaller study areas such as county levels can improve the accuracy of the land optimization process.

The study was limited to five impact factors. It is recommended that future studies should consider others such as earthquake susceptibility areas, fire prone locations, suitable soil, slopes, and access roads. Hot spot analysis will be essential to determine fatal crash hot spots using three to five consecutive years of fatality data.

\section{ACKNOWLEDGEMENTS}

The authors would like to thank the California State Departments for making GIS data files readily available. The authors appreciate the contributions of Santos Ramos, University of Texas - Rio Grande Valley, in data organization. The contents of this paper reflect the views of the authors, who are responsible for the facts and the accuracy of the information presented herein, and are not necessarily representative of any of the state departments in California.

\section{REFERENCES}

1. Raj, Rahul, et al. "Factors correlating with delayed trauma center admission following traumatic brain injury." Scandinavian journal of trauma, resuscitation and emergency medicine 21.1 (2013): 67.

2. Mississippi State Department of Health. Report to House and Senate Public Health and Welfare Committees. http://msdh.ms.gov/msdh/index.cfm/47,2622,313,386,pdf/ambulancestudy.pdf Accessed Feb. 26, 2017.

3. Census Bureau. California: 2010 Census of Population and Housing. CPH-2-6, August 2012. https://www.census.gov/prod/cen2010/cph-2-6.pdf. Accessed May 5, 2017. 
1 4. NHTSA. Fatality Analysis Reporting System. California Traffic Safety Facts. https://cdan.nhtsa.gov/SASStoredProcess/guest\#TAB1. Accessed May 5, 2017.

5. Caltrans, 2015. California Department of Transportation. SHSP Fact Sheet. http://www.dot.ca.gov/trafficops/shsp/docs/shsp_fact_sheet.pdf Accessed Nov. 25, 2016.

6. NHTSA. Traffic Safety Facts 2012. DOT HS 812 032. Washington, DC: National Highway Traffic Safety Administration. https://crashstats.nhtsa.dot.gov/Api/Public/ViewPublication/812032 Accessed Dec. 5, 2016.

7. SHSP, 2015 -2019. California Strategic Highway Safety Plan. http://www.dot.ca.gov/trafficops/shsp/docs/SHSP15_Update.pdf Accessed December 7, 2016.

8. Emergency Medical Services Authority. 2014 California State Trauma Plan. \#13-301. http://www.emsa.ca.gov/Media/Default/Commission\%20Meeting\%20Docs/March\%202015/ 6C_State_Trauma_Plan_Attachment.pdf Accessed Feb. 26, 2017.

9. California Office of Traffic Safety. Highway Safety Plan - 2016. https://www.nhtsa.gov/s/nhtsa.dot.gov/files/ca_fy16hsp.pdf Accessed Feb 26, 2017.

10. Collins, Michael G., Frederick R. Steiner, and Michael J. Rushman. "Land-use suitability analysis in the United States: historical development and promising technological achievements." Environmental management 28.5 (2001): 611-621.

11. Basnet, B. B., Apan, A. A., \& Raine, S. R. (2001). Selecting suitable sites for animal waste application using a raster GIS. Environmental Management, 28(4), 519-531.

12. Rodman, L. C., \& Meentemeyer, R. K. (2006). A geographic analysis of wind turbine placement in Northern California. Energy Policy, 34(15), 2137-2149.

13. Charabi, Y., \& Gastli, A. (2011). PV site suitability analysis using GIS-based spatial fuzzy multi-criteria evaluation. Renewable Energy, 36(9), 2554-2561.

14. Sánchez-Lozano, J. M., Teruel-Solano, J., Soto-Elvira, P. L., \& García-Cascales, M. S. (2013). Geographical Information Systems (GIS) and Multi-Criteria Decision Making (MCDM) methods for the evaluation of solar farms locations: Case study in south-eastern Spain. Renewable and Sustainable Energy Reviews, 24, 544-556.

15. Frazier, E. M. (2014). A Site Suitability Analysis for an Inland Port to Service the Ports of Los Angeles and Long Beach (Doctoral dissertation, University of Southern California).

16. Banai, Reza. "Fuzziness in geographical information systems: contributions from the analytic hierarchy process." International Journal of Geographical Information Science 7.4 (1993): 315-329.

17. Saaty, Thomas L. "Decision making with the analytic hierarchy process." International journal of services sciences 1.1 (2008): 83-98.

18. Bodily, Samuel E. Modern decision making: a guide to modelling with decision support systems. McGraw-Hill, 1985.

19. Malczewski, Jacek. "On the use of weighted linear combination method in GIS: common and best practice approaches." Transactions in GIS 4.1 (2000): 5-22.

20. Kritikos, Theodosios RH, and Timothy RH Davies. "GIS-based Multi-Criteria Decision Analysis for landslide susceptibility mapping at northern Evia, Greece [GIS-basierte multikriterielle Entscheidungsanalysen zur Kartierung von Massenverlagerungspotenzialen im nördlichen Evia, Griechenland.]." Zeitschrift der Deutschen Gesellschaft für Geowissenschaften 162.4 (2011): 421-434

21. Nefeslioglu, Hakan A., et al. "A modified analytical hierarchy process (M-AHP) approach for decision support systems in natural hazard assessments." Computers \& Geosciences 59 (2013): 1-8. 
22. Transportation Injury Mapping System (TIMS), 2016. University of California, Berkeley. https://tims.berkeley.edu/tools/gismap_old/\# Accessed Nov. 25, 2016.

23. California Department of Transportation. Caltrans GIS Data Library. http://www.dot.ca.gov/hq/tsip/gis/datalibrary/ Accessed Nov. 25, 2016.

24. California Department of Transportation. California Highway Safety Roadside Rest Areas. http://www.dot.ca.gov/hq/tsip/gis/datalibrary/Metadata/RestArea.html Accessed Nov. 25, 2016.

25. Office of Statewide Health Planning \& Development. California Healthcare Facilities Downloadable GIS data sets. http://www.oshpd.ca.gov/General_Info/Healthcare_Atlas.html Accessed Nov. 25, 2016.

26. California Department of Fish and Wildlife. https://www.wildlife.ca.gov/Data/GIS/Clearinghouse Accessed Nov. 25, 2016.

27. California National Park and Reserves. California Protected Areas Database http://www.calands.org/data Accessed Nov. 25, 2016.

28. California Department of Motor Vehicles. Driver Handbook - Laws and Rules of the Road. https://www.dmv.ca.gov/portal/dmv/detail/pubs/hdbk/speed_limits+. Accessed Dec. 7, 2016.

29. Stanford Medicine. eCampus Rural Health. http://ruralhealth.stanford.edu/healthpros/factsheets/ Accessed Feb. 26, 2017.

30. Mississippi State Department of Health. Report to House and Senate Public Health and Welfare Committees.

http://msdh.ms.gov/msdh/index.cfm/47,2622,313,386,pdf/ambulancestudy.pdf Accessed Feb. 26, 2017.

31. Daily News Journal. Budget proposal for EMS for Rutherford County. http://www.dnj.com/story/news/2015/03/26/budget-proposal-ems-includes-ambulancestation/70526854/ Accessed May 5, 2017. 